\title{
EDUKASI KESEHATAN DAN PSIKOLOGI PERKEMBANGAN ANAK PADA GURU SEKOLAH MINGGU DI SURABAYA
}

\section{EDUCATION OF HEALTH AND CHILD DEVELOMPENT PSYCHOLOGY AT SURABAYA}

\author{
Imelda Ritunga $^{\left.1^{*}\right)}$, Wira Wijaya Lindarto ${ }^{2)}$, Novensia Wongpy ${ }^{3)}$, Exanthie M. Jezua ${ }^{4)}$, \\ Bella M. Lifindra ${ }^{5)}$ \\ ${ }^{1,2,4,5}$ Fakultas Kedokteran Universitas Ciputra \\ ${ }^{3}$ Fakultas Psikologi Universitas Ciputra \\ ${ }^{1}$ Email: imelda.ritunga@ ciputra.ac.id
}

\begin{abstract}
Abstrak : Sekolah minggu adalah tempat berkumpulnya anak-anak untuk menumbuhkan kerohanian. Sekolah minggu memberikan pelayanan kepada anak-anak tanpa memandang latar belakang anak dari segi sosial, ekonomi, dan psikologi anak. Keberagaman latar belakang anak mempengaruhi perilaku di sekolah minggu, termasuk kebiasaan anak. Permasalahan yang timbul adalah ketika anak sekolah minggu sakit dan mengikuti kegiatan sekolah minggu dapat menularkan kepada lainnya. Guru sekolah minggu yang merupakan jemaat yang berkomitmen melayani tidak dibekali dengan pengetahuan kesehatan dan psikologi perkembangan anak. Permasalahan lainnya terbatasnya pengetahuan guru-guru sekolah minggu mengenai perilaku hidup bersih dan sehat (PHBS) untuk diajarkan ke anak-anak, sehingga setiap kali anak membuang sampah sembarangan terkadang dibersihkan oleh guru. Sarana tempat sampah kurang terfasilitasi di sekolah minggu dimana hanya 1 pada halaman sekolah minggu. Ruang dan Gudang penyimpanan alat dna bahan sekolah minggu tampak kotor dan kurang terawat. Alat dan bahan tidak memiliki tempat penyimpanan khusus seperti lemari, rak dan lainnya. Pengetahuan guru-guru terkait psikologi perkembangan anak juga minim sehingga pendekatan mengajar sesuai pengalaman masing-masing. Solusi yang ditawarkan adalah memberikan pelatihan dan pendampingan perilaku hidup bersih dan sehat, penyakit menular dan pencegahannya, pemeriksaan kesehatan kepada anak-anak sekolah minggu, serta penataan ruang sekolah minggu yang bersih dan menarik. Metode yang dilakukan dengan pelatihan, pendampingan, pemeriksaan kesehatan, dan penataan ruang dan gudang. Hasil kegiatan menunjukkan peningkatan pengetahuan guru sekolah minggu pada PHBS, pencegahan penyakit menular pada anak, dan psikologi perkembangan anak, serta penataan gudang dan ruang yang bersih dan rapi.
\end{abstract}

Kata Kunci : perilaku hidup bersih dan sehat, penyakit menular, psikologi anak, sekolah minggu

Abstract : Sunday school is a gathering place for children to grow spiritually. Sunday
school provides services to children regardless of the child's background in terms of the
social, economic, and psychological aspects of children. The diversity of children's
backgrounds influences their behavior in Sunday school, including children's habits. The
problem that arises is when children is sick and attending Sunday school activities can
transmit to others. Sunday school teachers who are congregations committed to serving
are not equipped with health knowledge and child development psychology. Another
problem is the limited knowledge of Sunday school teachers about clean and healthy
living behaviors (PHBS) to be taught to children, so that every time the child litteres,
sometimes they are cleaned by the teacher. The facilities for trash cans are less facilitated 


\section{INTEGRITAS : Jurnal Pengabdian}

Vol 4, No 1, Juli 2020

ISSN 2580 - 7978 (cetak) ISSN 2615 - 0794 (online)

at Sunday school where only on the Sunday school yard. The storage room and storage room and school materials looked dirty and poorly maintained. Tools and materials do not have special storage areas such as cabinets, shelves and others. Teachers' knowledge related to the psychology of child development is also minimal so that the teaching approach is in accordance with their individual experiences. The solution offered is to provide training and assistance in clean and healthy living behaviors, infectious disease prevention and prevention, health checks for Sunday school children, and the arrangement of clean and attractive Sunday school rooms. The method is carried out by training, assistance, health checks, and spatial planning and warehouse. The results of the activity showed an increase in the knowledge of Sunday school teachers on PHBS, prevention of infectious diseases in children, and the psychology of child development, as well as structuring clean and neat warehouses and spaces.

Keywords: clean and healthy life behavior, infectious diseases, child psychology, Sunday school

\section{PENDAHULUAN}

Kesehatan merupakan penting walaupun kadang tidak disadari oleh pemilik kesehatan. Seorangpun tidak ingin sakit tetapi seringkali penyakit datang tiba-tiba karena manusia lalai menjaga kesehatan. Penyakit menular adalah salah satu penyakit yang telah lama dikenal oleh manusia dan menimbulkan masalah kematian maupun kecacatan bagi penderitanya. Penyakit ini disebabkan oleh mikroorganisme dan dapat ditularkan atau berpindah ke manusia sehat lainnya. Menurut hasil Riset Kesehatan Darat (Riskedas) yang dilakukan oleh badan lingkungan kementerian kesehatan Republik Indonesia pada tahun 2018, penyakit infeksi menempati peringkat ketiga sebagai penyebab sakit di Indonesia. Data Dinas Kesehatan terkait 10 penyakit terbanyak di Surabaya di dapatkan penyakit saluran pernapasan menempati urutan tertinggi. Penyakit saluran pernapasan atas merupakan penyakit yang umumnya menularkan melalui droplet.

Resiko penularan agen patogen lebih besar pada usia anak dengan imunitas rentan di lingkungan yang penuh sesak dan atau tempat berkumpul anak. Hal ini tentu tidak baik bagi kesehatan anak dan akan mengganggu pertumbuhan anak jika sering mengalami sakit karena infeksi dari penularan sekitarnya. Beberapa hal yang mempengaruhi penyebaran penyakit pada anak antara lain status gizi, status imunisasi, umur, musim, kemampuan menjaga higienitas, kepadatan kumpulan dan karakteristik lingkungan dari fasilitas berkumpulnya 


\section{INTEGRITAS : Jurnal Pengabdian}

Vol 4, No 1, Juli 2020

ISSN 2580 - 7978 (cetak) ISSN 2615 - 0794 (online)

anak-anak. Pengetahuan orang tua mengenai perilaku hidup bersih dan sehat (PHBS) serta pengetahuan tentang penyakit menular dan cara pencegahannya akan mempengaruhi angka kejadian penyakit di tempat tersebut.

Perilaku hidup bersih dan sehat (PHBS) menjadi salah satu upaya menjaga kesehatan. PHBS adalah sekumpulan perilaku yang dipraktekkan atas dasar kesadaran dari hasil pembelajaran, yang menjadikan seseorang, keluarga, kelompok atau masyarakat mampu menolong dirinya sendiri (mandiri) di bidang kesehatan dan berperan aktif dalam mewujudkan kesehatan di lingkungannya. PHBS perlu ditularkan agar keluarga, komunitas, dan masyarakat dapat hidup sehat. Awal dari menularkan adalah penyadartahuan yang dilakukan melalui edukasi. Pengetahuan dan sikap mengenai kesehatan akan berpengaruh terhadap perilaku sebagai hasil jangka panjang dari pendidikan kesehatan. Hal itu dikarenakan dari pengetahuan dan sikap akan terbentuk kesadaran dan upaya untuk pencegahan. Hasil studi bidang neurologi menyatakan perkembangan kognitif anak telah mencapai $50 \%$ pada usia 4 tahun, dan $80 \%$ pada usia 8 tahun, secara psikis juga mengalami perkembangan. Pemahaman aspek psikologis peserta didik memiliki kontribusi yang sangat berarti dalam pembelajaran peserta didik sesuai dengan sikap, minat, motivasi, aspirasi, dan kebutuhan peserta didik, sehingga proses pembelajaran dapat berlangsung secara optimal dan maksimal.

Penyakit dapat terjadi pada siapa saja termasuk pada guru dan anak sekolah minggu dan dapat menularkan ke lingkungannya karena minim pengetahuan akan penyakit menular dan pencegahannya. Guru sekolah minggu merupakan jemaat yang rindu dan sukarela membantu di sekolah minggu. Latar belakang guru sekolah minggu beragam dari pendidikan dan sosioekonominya. Permasalahan yang yang didapatkan dari hasil diskusi dan observasi dengan mitra guru sekolah minggu adalah keterbatasan pengetahuan guru-guru sekolah minggu mengenai kesehatan menjadi kendala dalam mengidentifikasi dan mencegah penularan penyakit di lingkungan sekolah minggu. Hal ini termasuk keterbatasan untuk mengedukasi anak-anak sekolah minggu tentang kesehatan. Di samping itu, guru- guru sekolah minggu minim pengetahuan mengenai psikologi 
INTEGRITAS : Jurnal Pengabdian

Vol 4, No 1, Juli 2020

ISSN 2580 - 7978 (cetak) ISSN 2615 - 0794 (online)

perkembangan anak yang berguna dalam mengajar di sekolah minggu. Anak-anak setiap kali membuang sampah sembarangan terkadang dibersihkan oleh guru, hal ini tidak merubah perilaku anak-anak akan kebersihan. Di tambah sarana penunjang kurang memadai seperti bak sampah hanya ada di halaman sekolah minggu. Gudang sekolah minggu tidak bersih karena tidak memiliki lemari dan kabinet. Hal ini dapat menjadi sarang nyamuk yang berpotensi menimbulkan penyakit. Hal ini tentu tidak baik bagi anak-anak dan bagi guru. Hal ini sejalan dengan penelitian Wulandari yang menemukan fakta dilapangan pada lembaga pendidikan anak usia dini menyatakan kesulitan menerapkan pendidikan kesehatan dikarenakan kurangnya informasi tentang pendidikan kesehatan yang seharusnya dilakukan. ${ }^{7}$ PHBS di sekolah merupakan langkah untuk memberdayakan siswa, guru dan masyarakat lingkungan sekolah agar bisa dan mau melakukan perilaku hidup sehat dan bersih dalam menciptakan sekolah yang sehat.

Potensi yang dimiliki Sekolah Minggu ini adalah: 1) sudah memiliki tempat untuk kegiatan sekolah minggu yang menetap berupa rumah, 2) Guru-guru merupakan jemaat yang rindu dan berkomitmen melayani di skeolah minggu, 3) Guru-guru adalah jemaat gereja yang memiliki anak-anak yang bersekolah minggu, 4) Jumlah anak-anak sekolah minggu berkisar 25-40 tiap aktivitas.

Kegiatan pengabdian masyarakat ini perlu dilakukan untuk meningkatkan kesehatan di lingkungan sekolah minggu. Solusi yang diberikan berupa pelatihan di bidang kesehatan dan psikologi, berupa edukasi PHBS, Pencegahan penyakit menular, psikologi perkembangan anak. Setelah itu dilakukan pendampingan pada guru sekolah minggu yang menularkan edukasi PHBS dalam bentuk sederhana yaitu mengajarkan kebiasaan mencuci tangan enam langkah versi WHO. Juga dilakukan bantuan pengadaan sarana pendukung pembelajaran pada gudang dan ruang belajar. 


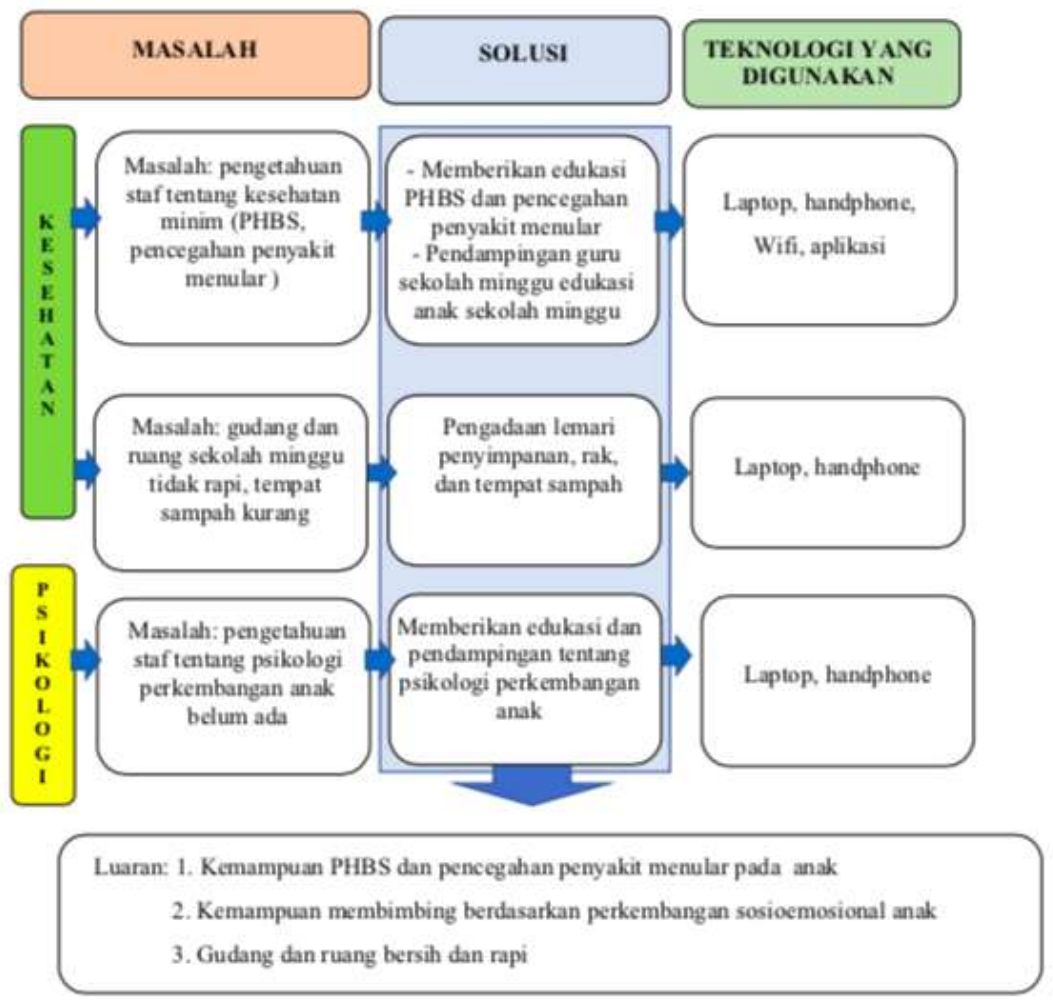

Gambar 1. Visualisasi gambaran IPTEK

\section{METODE PELAKSANAAN}

Strategi pelaksanaan yang digunakan untuk membantu mitra adalah dengan edukasi kepada guru sekolah minggu, praktek keterampilan PHBS dan Pencegahan Penyakit Menular, Pendampingan Guru Sekolah Minggu pada edukasi PHBS dan Pencegahan Penyakit Menular kepada anak sekolah minggu, serta pengadaan kelengkapan ruang sekolah minggu yang. Tahapan pelaksanaan terdiri dari:

\section{Tahap Persiapan}

Persiapan kegiatan yaitu observasi awal dan rapat koordinasi dengan tim mitra untuk mendapatkan gambaran Sekolah Minggu, kebutuhan dan harapan mitra untuk kegiatan ini, menentukan koordinator tim mitra, dan menentukan waktu serta tempat pelaksanaan. Koordinator tim bertugas mengkoordinasikan anggota yang akan mengikuti Edukasi dengan tim pelaksana. Jumlah peserta 
INTEGRITAS : Jurnal Pengabdian

Vol 4, No 1, Juli 2020

ISSN 2580 - 7978 (cetak) ISSN 2615 - 0794 (online)

yang akan mengikuti penyuluhan sebanyak 8 guru sekolah minggu dan membuka kesempatan bagi orang tua pemerhati anak sekolah minggu yang berminat.

2. Tahap Implementasi

Pelaksanaan kegiatan terdiri dari pelatihan dan simulasi keterampilan pada guru sekolah minggu, Pada kegiatan pelaitihan ini terdiri dari tiga materi dan praktek simulasi, yaitu:
a. Perilaku Hidup Bersih dan Sehat (PHBS)
b. Pencegahan penyakit menular pada anak
c. Praktek simulasi cuci tangan enam Langkah versi WHO
d. Psikologi perkembangan anak dan remaja

3. Tahap Evaluasi

Evaluasi pelaksanaan pelatihan berupa evaluasi kegiatan dan penilaian hasil edukasi. Evaluasi kegiatan untuk melihat persepsi partisipan pada kegiatan dan penilaian hasil edukasi untuk melihat ada tidaknya peningkatan pengetahuan.

4. Tahap Pendampingan

Pendampingan dilakukan saat pertemuan sekolah minggu dimana guru sekolah minggu memberikan pengetahuan dan praktek simulasi bersama mencuci tangan enam langkah versi WHO sebagai bagian dari PHBS dan pencegahan penyakit menular.

5. Bidang penataan ruang berupa bantuan alat pendukung pembelajaran dan penyimpanan alat bahan sekolah minggu agar bersih dan sehat.

\section{HASIL DAN PEMBAHASAN}

1. Tahap Persiapan dan Implementasi

Kegiatan Edukasi Kesehatan dan psikologi perkembangan anak dilakukan pada hari Sabtu, 29 Februari 2020, bertempat di Gedung Pondok Daud Diaspora Surabaya. Kegiatan dihadiri oleh 11 partisipan berupa delapan guru sekolah mingu dan tiga orang tua pemerhati anak sekolah minggu. Pelatihan ini mengukur 
INTEGRITAS : Jurnal Pengabdian

Vol 4, No 1, Juli 2020

ISSN 2580 - 7978 (cetak) ISSN 2615 - 0794 (online)

pengetahuan peserta melalui pre test di awal dan di akhir berupa post test serta evaluasi pelatihan. Kegiatan pelatihan berupa:

a. Edukasi " Perilaku Hidup Bersih dan Sehat"

Proses pelaksanaan kegiatan berupa sesi penyampaian materi edukasi, dan sesi tanya jawab dan diskusi. Tujuan edukasi ini adalah untuk meningkatkan pengetahuan guru sekolah minggu akan pentingnya PHBS dan langkahlangkahnya. Pada diskusi juga dibahas langkah-langkah PHBS yang bisa dilakukan di sekolah minggu.

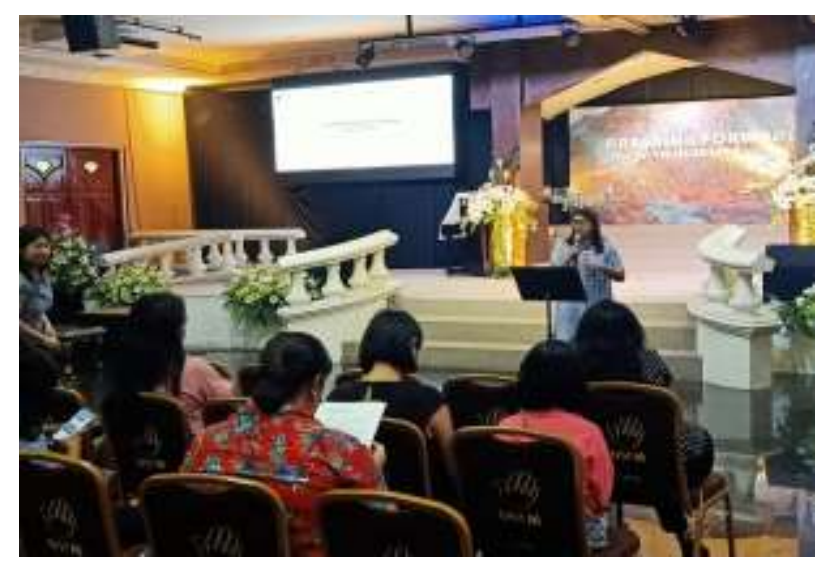

Gambar 2. Edukasi PHBS

b. Edukasi "Pencegahan Penyakit Menular pada Anak"

Proses pelaksanaan kegiatan berupa sesi penyampaian materi edukasi, dan sesi tanya jawab dan diskusi. Tujuan edukasi ini adalah agar peserta dapat mengidentifikasi penyakit menular dan bagaimana pencegahannya. Pada diskusi juga dibahas kegiatan dan dukungan guru sekolah minggu untuk mencegah penyakit menular di sekolah minggu dan keluarga. 


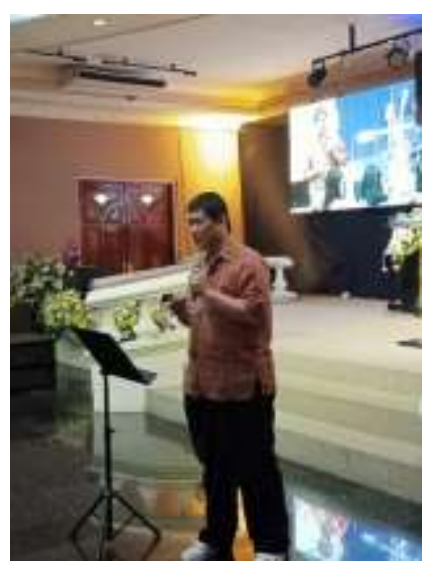

Gambar 3. Edukasi Pencegahan Penyakit Menular pada anak

c. Praktek simulasi "Cuci Tangan enam Langkah versi WHO"

Proses pelaksanan praktek simulasi: a) simulasi cuci tangan enam langkah versi WHO yang dilakukan oleh pemateri, berikutnya b) simulasi yang dilakukan sambal menyebut tiap langkah, selanjutnya c) pemateri bersama peserta mensimulasikan enam langkah cuci tangan versi WHO, dan d) peserta mensimulasikan mandiri enam langkah cuci tangan versi WHO d. Edukasi " Psikologi perkembangan anak dan remaja"

Proses pelaksanaan kegiatan berupa sesi penyampaian materi edukasi, dan sesi tanya jawab dan diskusi. Tujuan edukasi ini adalah untuk meningkatkan pengetahuan guru sekolah minggu akan perkembangan sosio-emosional anak sesuai usia. Hal ini menjadi bekal guru dalam pembimbingan di sekolah minggu.

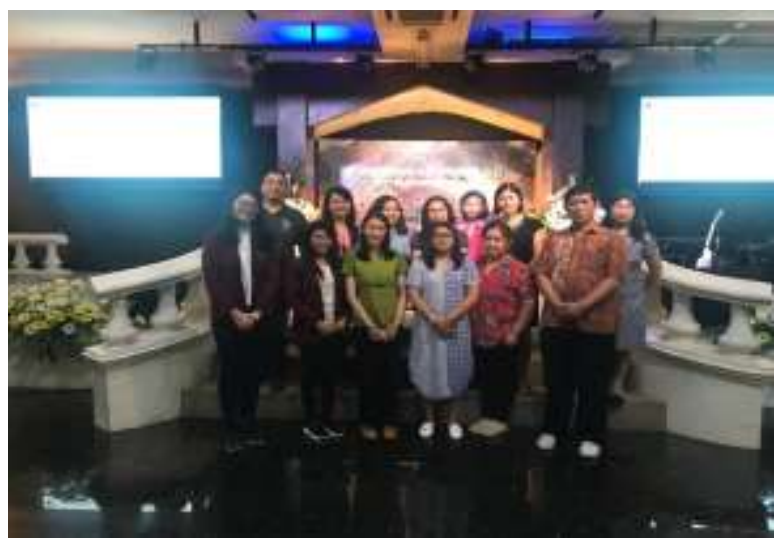

Gambar 4. Pemateri dan peserta kegiatan 
INTEGRITAS : Jurnal Pengabdian

Vol 4, No 1, Juli 2020

ISSN 2580 - 7978 (cetak) ISSN 2615 - 0794 (online)

2. Tahap Evaluasi

Evaluasi dilakukan dengan mengukur:

a. Peningkatan pengetahuan sebelum/pre dan setelah/post pelatihan.

Hasil pre dan post test (grafik) gambar berikut.

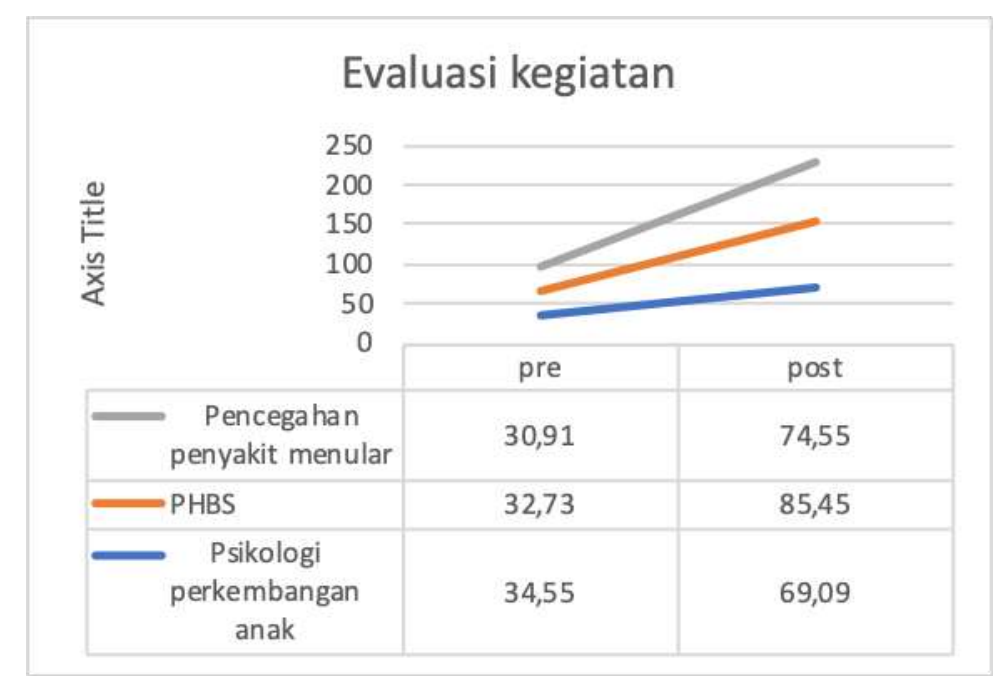

Gambar 5. Peningkatan pengetahuan partisipan

Gambar grafik diatas menunjukkan peningkatan pengetahuan sebelum dan setelah edukasi pencegahan penyakit menular, PHBS, dan psikologi perkembangan anak. Peningkatan pengetahuan diharapkan menjadi dasar bagi guru sekolah minggu dalam melakukan PBHS di lingkung keluarga dan sekolah minggu, mengidentifikasi penyakit menular dan melakukan pencegahan terhadap penyakit, serta dapat membimbinga anak dengan bekal pengethaun psikologi perkembangan anak.

b. Persepsi peserta pada kegiatan pelatihan.

Hasil evaluasi kegiatan berupa quesioner kepuasan kegiatan yang diberikan kepada peserta di akhir kegiatan. Hasil yang didapat menunjukkan partisipan puas pada kegiatan ini. 


\section{INTEGRITAS : Jurnal Pengabdian}

Vol 4, No 1, Juli 2020

ISSN 2580 - 7978 (cetak) ISSN 2615 - 0794 (online)

\section{Tahap Pendampingan}

Tahap pendampingan dilakukan via daring zoom dikarenakan kegiatan dilakukan di masa pandemi covid 19. Kegiatan pendampingan berupa:

a. Zoom bersama guru sekolah minggu mendiskusikan langkah-langkah yang hendak dilakukan untuk menumbuhkan PHBS

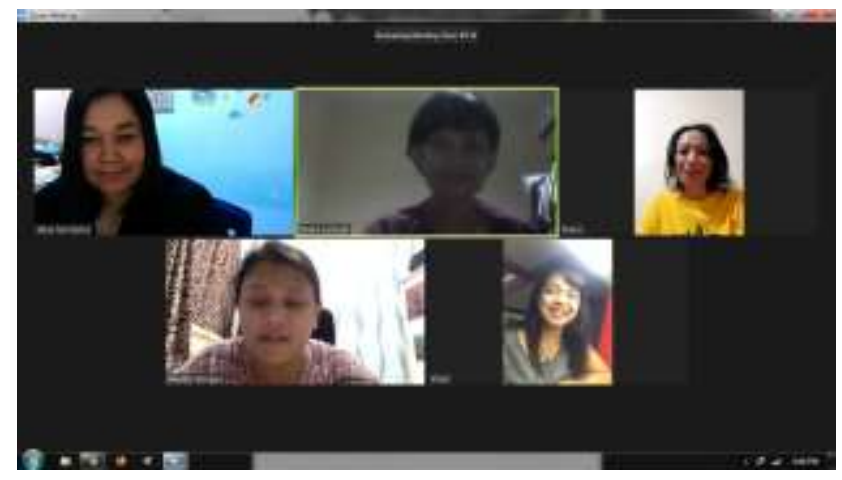

Gambar 6. Pendampingan Guru Sekolah Minggu

b. Zoom pendampingan guru sekolah minggu memberikan simulasi cuci tangan enam langkah kepada anak-anak skeolah minggu.
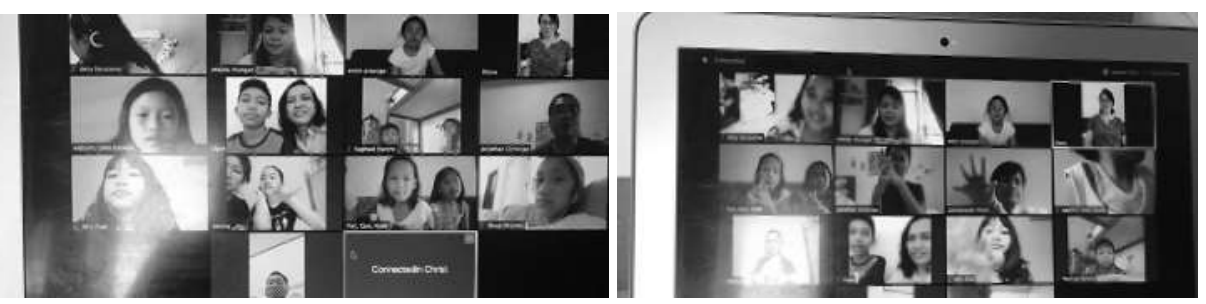

Gambar 7. Pendampingan sekolah minggu memberikan simulasi cuci tangan enam langkah kepada anak-anak sekolah minggu

\section{Tahap penataan ruang dan Gudang}

Sebagai rangkaian dari pelatihan Kesehatan, dukungan terhadap hygiene dan sanittasi ruang sekolah minggu dilakukan berupa bantuan tempat sampah, pendukung pembelajaran, dan penyimpanan alat dan bahan di sekolah minggu lebih bersih dan tertata rapi. Gudang yang bersih tidak menjadi sarang nyamuk yang dapat menularkan penyakit, adanya tempat sampah pada ruang utama dan kelas menjadi fasilitas untuk melatih anak membuang sampah pada tempatnya, 
INTEGRITAS : Jurnal Pengabdian

Vol 4, No 1, Juli 2020

ISSN 2580 - 7978 (cetak) ISSN 2615 - 0794 (online)

serta sarana pendukung pembelajaran berupa white board, papan flanel, meja gambar anak diharapkan membantu pembelajaran yang baik dan menyenangkan.

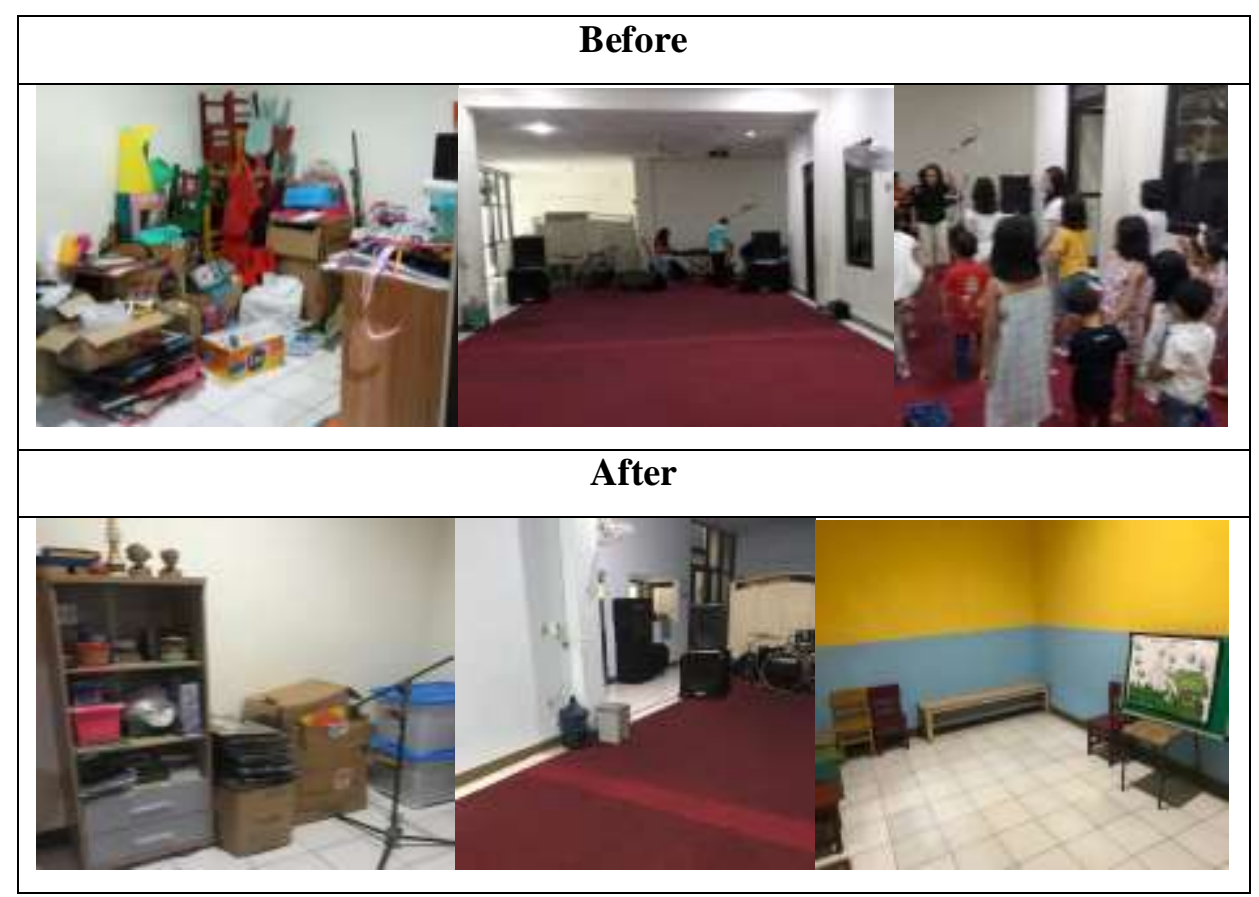

Gambar 8. Ruang dan Gudang skeolah minggu

\section{KESIMPULAN}

Kegiatan pengabdian masyarakat berjalan lancar. Mitra antusias berpartisipasi pada kegiatan menularkan kepada anak-anak Sekolah Minggu. Hasil evaluasi edukasi menunjukkan peningkatan pengetahuan staf tentang Pencegahan Penyakit Menular pada Anak, Pola Hidup Bersih dan Sehat, dan Psikologi Perkembangan Anak. Guru Sekolah Minggu dapat mengedukasi dan menerapkan tindakan sehat di sekolah minggu. Guru Sekolah Minggu dapat membimbing dengan bekal pengetahuan sosioemosional anak seusai masa perkembangannya. Hasil pengabdian juga menolong mitra pada masa pandemic ini untuk mempersiapkan diri dan sekolah minggu menghadapi "New Normal" dengan pola hidup bersih dan sehat. 
INTEGRITAS : Jurnal Pengabdian

Vol 4, No 1, Juli 2020

ISSN 2580 - 7978 (cetak) ISSN 2615 - 0794 (online)

\section{UCAPAN TERIMA KASIH}

Terima kasih kepada LPPM Universitas Ciputra yang telah mendukung dan mensupport pelaksanaan kegiatan pengabdian masyarakat ini.

\section{DAFTAR PUSTAKA}

Badan Penelitian dan Pengembangan Kesehatan Kementerian Kesehatan RI. 2018. Hasil Utama Riskesdas.

Dinas Kesehatan Provinsi Jawa Timur. 2014. Profil Kesehatan Provinsi Jawa Timur. Surabaya: Dinas Kesehatan Provinsi Jawa Timur. http://dinkes.surabaya.go.id/portal/profil/dkk-dalam-angka/statistik-10penyakit-terbanyak/

Dodi N. Pentingnya guru unutk mempelajari psikologi pendidikan. Jurnal Ilmu Pengetahuan Sosial, Vol.1 Des.2016. ISSN 2541-657X.

Kementerian Kesehatan RI. 2011. Pedoman Pembinaan Perilaku Hidup Bersih dan Sehat (PHBS). Jakarta.

Long S.S., Pickering L.K., Prober C.G. 2012. Principles and Practice of Pediatric Infectious Diseases 4th Edition. Elsevier Saunders

Oliviera,P.D. et al. 2019. Day care attandance during the first 12 months of life and occurance of infectious morbidity and symptoms. Journal de Pediatriae, 95(6), pp.657-666. Doi:10.1016/j.jped.2018.05.012.

Wulandari, H. Pelaksanaan Pendidikan Kesehatan Perilaku Hidup Bersih dan Sehat (PHBS) pada Anak Usia Dini di TK ABA Tegalsari Yogyakarta. Tesis. Uniersitas Islam Sunan Kalijaga. Yogyakarta. Diperoleh dari http://digilib.uin-suka.ac.id/6824/ 